\title{
29. MID-CRETACEOUS RADIOLARIANS FROM THE EASTERN EQUATORIAL ATLANTIC AND THEIR PALEOCEANOGRAPHY ${ }^{1}$
}

\author{
Jochen Erbacher ${ }^{2}$
}

\begin{abstract}
Distinct intervals from cores recovered at Holes 959D and 962B of Ocean Drilling Program Leg 159 have yielded Cretaceous radiolarians. The recovered faunas are of late Albian to uppermost Cenomanian (in intervals 159-962B-8H-4, 85-86 cm, to $159-962 \mathrm{~B}-10 \mathrm{H}-\mathrm{CC}$ ), late Turonian to Santonian (in intervals $159-962 \mathrm{~B}-8 \mathrm{H}-4,2-4 \mathrm{~cm}$, to $159-962 \mathrm{~B}-8 \mathrm{H}-4,24-28 \mathrm{~cm}$ ) and Campanian age (Sections 159-959D-61R-1 through 3). Preservation of the faunas is moderate to poor. While the Campanian fauna generally reflect the typical low- to mid-latitude associations known from the North Atlantic and Alpine realm, midCretaceous radiolarian assemblages show certain differences to those known from the North Atlantic and Tethys. The similarities of the observed faunas to those from the North Atlantic and Tethys seem to increase with the ongoing opening of the Equatorial Atlantic Gateway. Differences between the late Albian faunas of both basins are significant. All of the observed faunas are of a remarkably low diversity. The diversity and the similarity to Tethyan faunas increase toward the late Cenomanian. As very little knowledge exists about late Turonian to Santonian assemblages, comparisons between the observed fauna and their definite ages remain difficult.

Radiolarian-bearing intervals correlate well with the radiolarian-rich time intervals of other basins and, therefore, support former observations of a correlation of radiolarian intervals and mid-Cretaceous oceanic events. The observed radiolarian-rich intervals (late Albian, pre-Oceanic Anoxic Event [OAE] 1d; late Cenomanian, pre- OAE 2, and Campanian, OAE 3) correlate well with times of transgressive sea level.
\end{abstract}

\section{INTRODUCTION}

The knowledge of mid-Cretaceous radiolarians has improved during the last 20 years because of many stratigraphic and taxonomic studies, as well as a few ecological studies. While most of them focused on radiolarians from the Tethys, Pacific, and North Atlantic (Pessagno, 1976; Pessagno, 1977; Schaaf, 1984; Thurow, 1988; Erbacher, 1994; O’Dogherty, 1994), hardly any data exist on faunas from the South Atlantic (Foreman, 1978; Ling and Lazarus, 1990). The recovery of mid-Cretaceous radiolarians during Leg 159 provides new information on the taxonomy, biogeography, and stratigraphy of radiolarians and gives new insights into the history of the opening of the Equatorial Atlantic Gateway.

This paper focuses on the preliminary results of my studies of Cretaceous radiolarians from Leg 159, specifically in the Albian to Coniacian (to Santonian?) assemblages.

\section{MATERIAL AND METHODS}

Hole $962 \mathrm{~B}\left(3^{\circ} 15.063^{\prime} \mathrm{N}, 3^{\circ} 10.919^{\prime} \mathrm{W}\right)$ has been drilled at a water depth of $4637 \mathrm{~m}$. It is located at the base of the continental slope close to the Côte d'Ivoire-Ghana Marginal Ridge (Fig. 1). Cores 159$962 \mathrm{~B}-8 \mathrm{H}$ through $10 \mathrm{H}$ have been sampled. Radiolarians appeared in Sections 159-962B-8H-4 through 8H-CC, in most of the samples of Core 159-962B-9H, and in the core catcher of Core 159-962B-10H (Table 1). An unconformity in Sample 159-962B-8H-4, $80 \mathrm{~cm}$, separates a pale green glauconite-rich claystone from a pale green claystone with cherts. The latter lithology is strongly brecciated (because of drilling disturbances?) and continues to Section 159-962B-8H-

${ }^{1}$ Mascle, J., Lohmann, G.P., and Moullade, M. (Eds.), 1998. Proc. ODP, Sci. Results, 159: College Station, TX (Ocean Drilling Program).

${ }^{2}$ Erbacher, J. Institut für Geologie und Paläontologie, Universität Tübingen, Sigwartstraße 10, D-72076 Tübingen, Federal Republic of Germany. (Present address: Bundesanstalt für Geowissenschaften und Rohstoffe, Referat Meeresgeologie, Postfach 510153, 0631 Hannover, Federal Republic of Germany.) j.erbacher@bgr.de
CC. Calcareous nannoplankton and planktonic foraminifers suggest the age of the breccia to be Albian to Cenomanian (Bellier, Chap. 27; Watkins et al., Chap. 26, both this volume). Core 159-962B-9H to Section 159-962B-10H-CC consists of dark cherts and pyrite-rich claystone also brecciated by coring. Benthic and planktonic foraminifers indicate a late Albian age (Bellier, Chap. 27; Holbourn and Moullade, Chap. 28, both this volume). The abundance of radiolarians is generally rare to common (Fig. 2). The preservation varies from very poor to moderate.

Sediment samples $\left(10 \mathrm{~cm}^{3}\right)$ were treated and broken down with distilled water. Clay-rich samples have been treated with a mixture of $50 \%$ anionic detergent (REWOQUAD) and 50\% alcohol. Samples were washed over a $63-\mu \mathrm{m}$ net. The residue $>63 \mu \mathrm{m}$ was analyzed, studied under a reflected light stereoscopic microscope, and photographed using the scanning electron microscope (SEM). For SEM, specimens have been mounted on SEM stubs with double sided tape and coated with platinum.

Relative abundances are based on population counts of the entire residue $($ Table 1$): \mathrm{x}=$ one specimen; $\mathrm{r}$ (rare) $=$ from two to five specimens; $\mathrm{f}(\mathrm{few})=$ from six to 10 specimens; and $\mathrm{c}(\mathrm{common})=$ from 11 to 20 specimens.

\section{BIOSTRATIGRAPHY}

Radiolarians from Cores $159-962 \mathrm{~B}-8 \mathrm{H}$ through $10 \mathrm{H}$ were subdivided into three different intervals characterized by different preservation and radiolarian assemblages.

The first interval (159-962B-8H-4, 2-28 cm) reveals a fauna of moderate to poor preservation. Radiolarians are replaced by opal-CT and show overgrowth of zeolite (clinoptylolite) crystals (Fig. 2; T. Pletsch, pers. comm., 1996). The age of the assemblages is problematic. However, the lack of typical Campanian forms that were observed in Core 159-959D-61R (W. Kuhnt, pers. comm., 1996) and the absences of Cenomanian morphotypes, which appear downsection, indicate a late Turonian to Santonian age (Table 1). As little knowledge exists about radiolarians of Turonian to Santonian age, a 
Figure 1. Location map of drilled sites of ODP Leg 159 showing the Côte d'Ivoire-Ghana Marginal

Ridge and surrounding areas. Mid-Cretaceous radiolarians have been observed in Hole 962B (Basile et al., 1996).

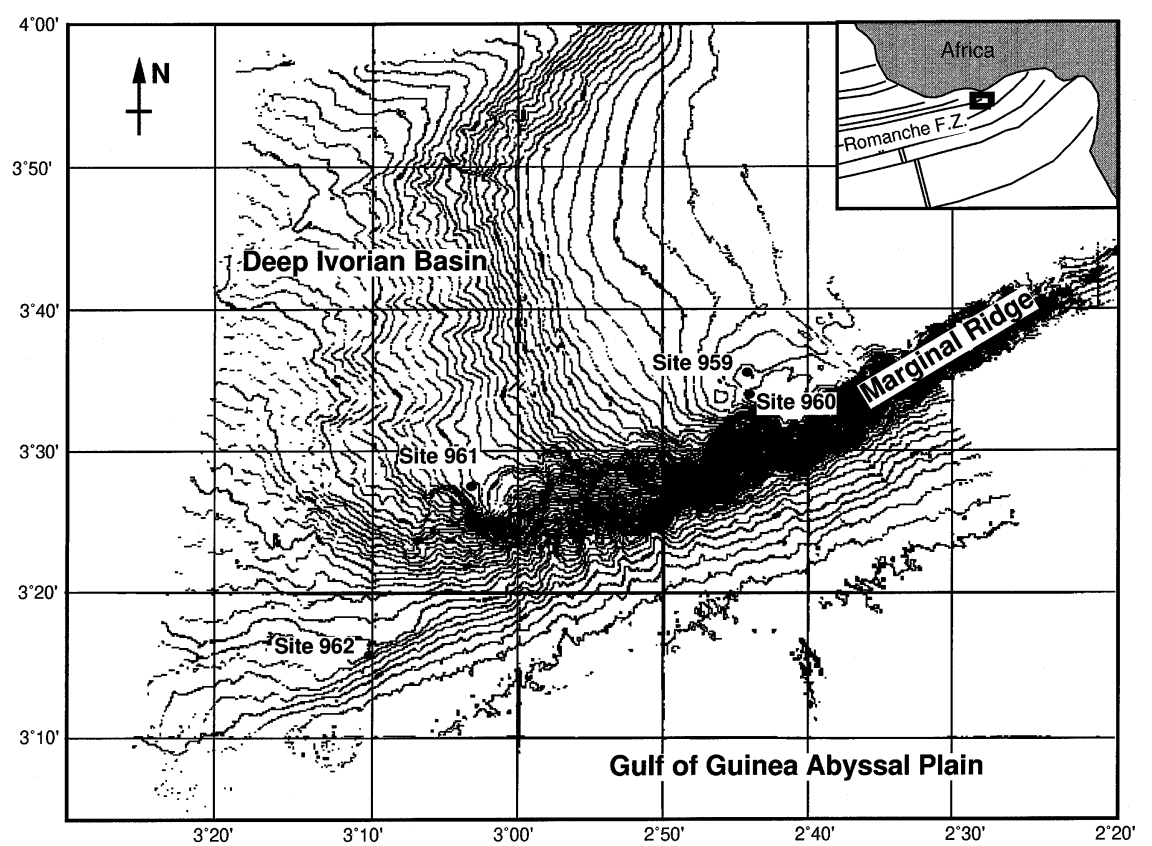

be endemic and may be restricted to the northern South Atlantic or are of an austral origin.

The third interval (159-962B-9H-1 through $10 \mathrm{H}-\mathrm{CC})$ is again characterized by opal-CT-replaced radiolarians. The diversity of the fauna is very low; small to tiny forms are dominating the samples. The remarkable decrease in size from Core 159-962B-8H through $9 \mathrm{H}$ is paralleled by an increase of the ratio of spumellaria and cryptocephalic nasselaria to elongated nasselaria. The presence of Albian to Cenomanian taxa and the absence of typical Cenomanian forms as observed farther upsection suggest a late Albian age of the fauna. The known range from Alievum sculptus and Novixitus mclaughlini is middle Albian to Cenomanian, Cavaspongia sphaerica has been observed in late Albian to Turonian sediments, and Obiculiforma maxima is recorded from the late Aptian to Turonian. The co-occurence of these taxa with Pseudodictyomitra lodogaensis that has a wellestablished range from the late Aptian to late Albian indicates a late Albian age of this interval. In Tethyan and North Atlantic sections, $P$. lodogaensis has not been observed in sediments younger than the late Albian Rotalipora ticinensis planktonic foraminifer zone. The known first occurrence of $C$. sphaerica lies within the same zone. This might indicate a middle late Albian (R. ticinensis planktonic foraminifer zone, Pseudodictyomitra pseudomacrocephala radiolarian zone, Erbacher and Thurow, in press) age for Cores 159-162B-9H through $10 \mathrm{H}$. If the upper part for Core 159-962B-9H is middle-late Albian in age, this would imply that the Vraconian is either very reduced or missing. No clear Vraconian faunal elements have been identified in samples from Core 159-162B-8H. Again, the observed fauna shows numerous signs of an endemic character. The lack of typical forms and a comparably very low diversity (in general, late Albian faunas are characterized by remarkably high diversities, (Erbacher and Thurow, 1997), together with a dominance of spumellaria and cryptocephalic nasselaria clearly distinguishes this fauna from timeequivalent Tethyan assemblages.

\section{PALEOBIOGEOGRAPHY AND PALEOCEANOGRAPHY}

Mid-Cretaceous radiolarians of Hole 962B add some interesting insights into the opening of the Equatorial Atlantic Gateway and general radiolarian paleobiogeography. The first faunal migrations, as a 
Table 1. Occurrence and range of late Albian to Cenomian and ?Coniacian to Santonian radiolarians from Hole 962B.

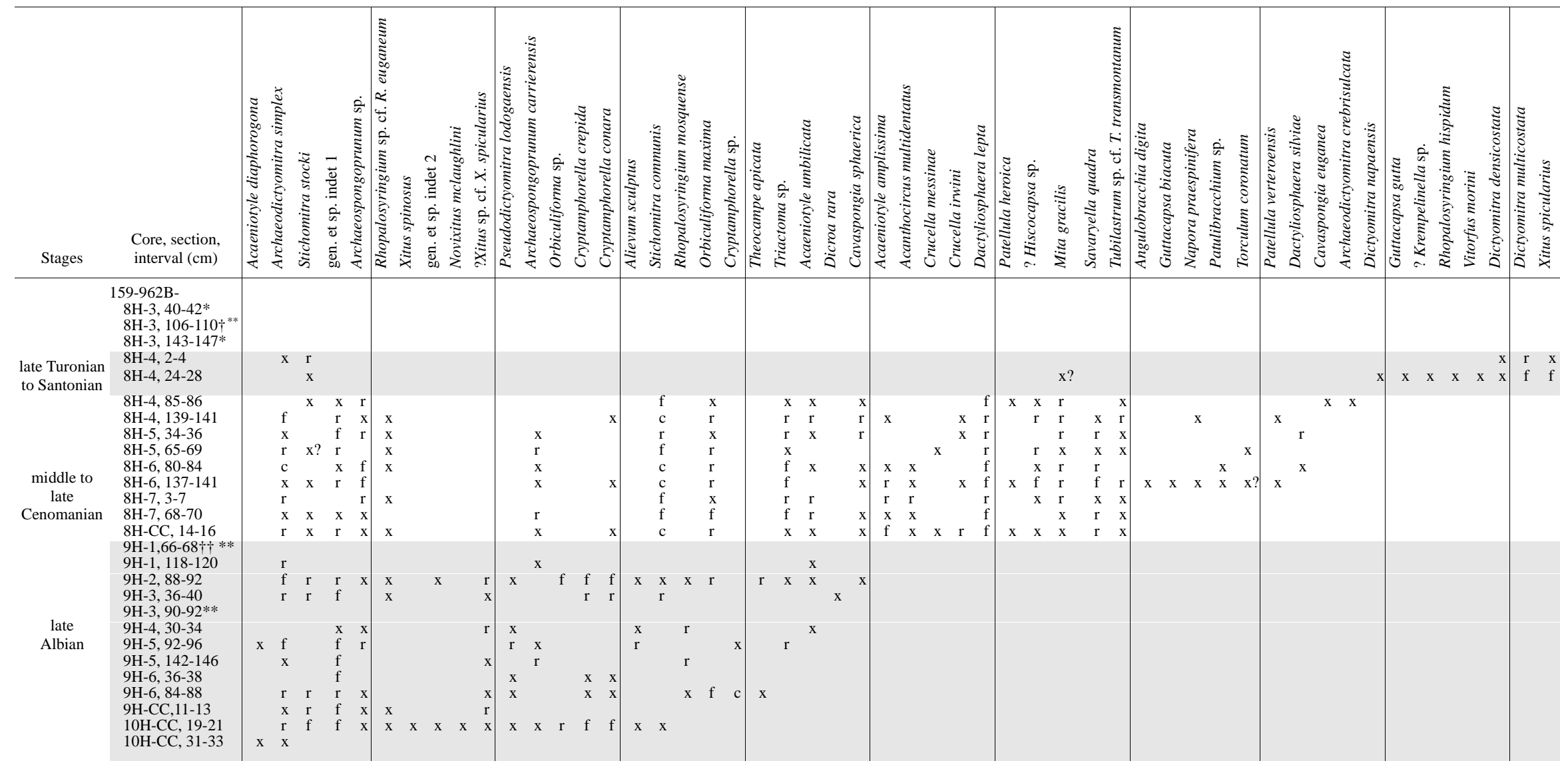

Note: $*=$ no radiolarians, $\dagger=$ radiolarians rare, $* *$ radiolarians very poor, $\dagger \dagger=$ radiolarians very rare, gen. et sp. indet $=$ genus and species indeterminate 
Figure 2. Radiolarian biostratigraphy and radiolarian abundance summary of the late Albian to ?Santonian interval of Hole 962B. Indicated are sub-bottom depth, core recovery and lithology. Radiolarian abundances are divided into $\mathrm{r}$ (rare) $=<20$ radiolarians per $10 \mathrm{~cm}^{3}, \mathrm{f}(\mathrm{few})=<50$ radiolarians per $10 \mathrm{~cm}^{3}, \mathrm{c}$ (common) $=<80$ radiolarians per $10 \mathrm{~cm}^{3}$, and a (abundant $)=>80$ radiolarians per $10 \mathrm{~cm}^{3}$. See biostratigraphy section of this chapter for tentative mid-Cretaceous radiolarian zonation of Hole 962B. Graphic lithology modified after the "Principal Results" chapter, Shipboard Scientific Party (1996).

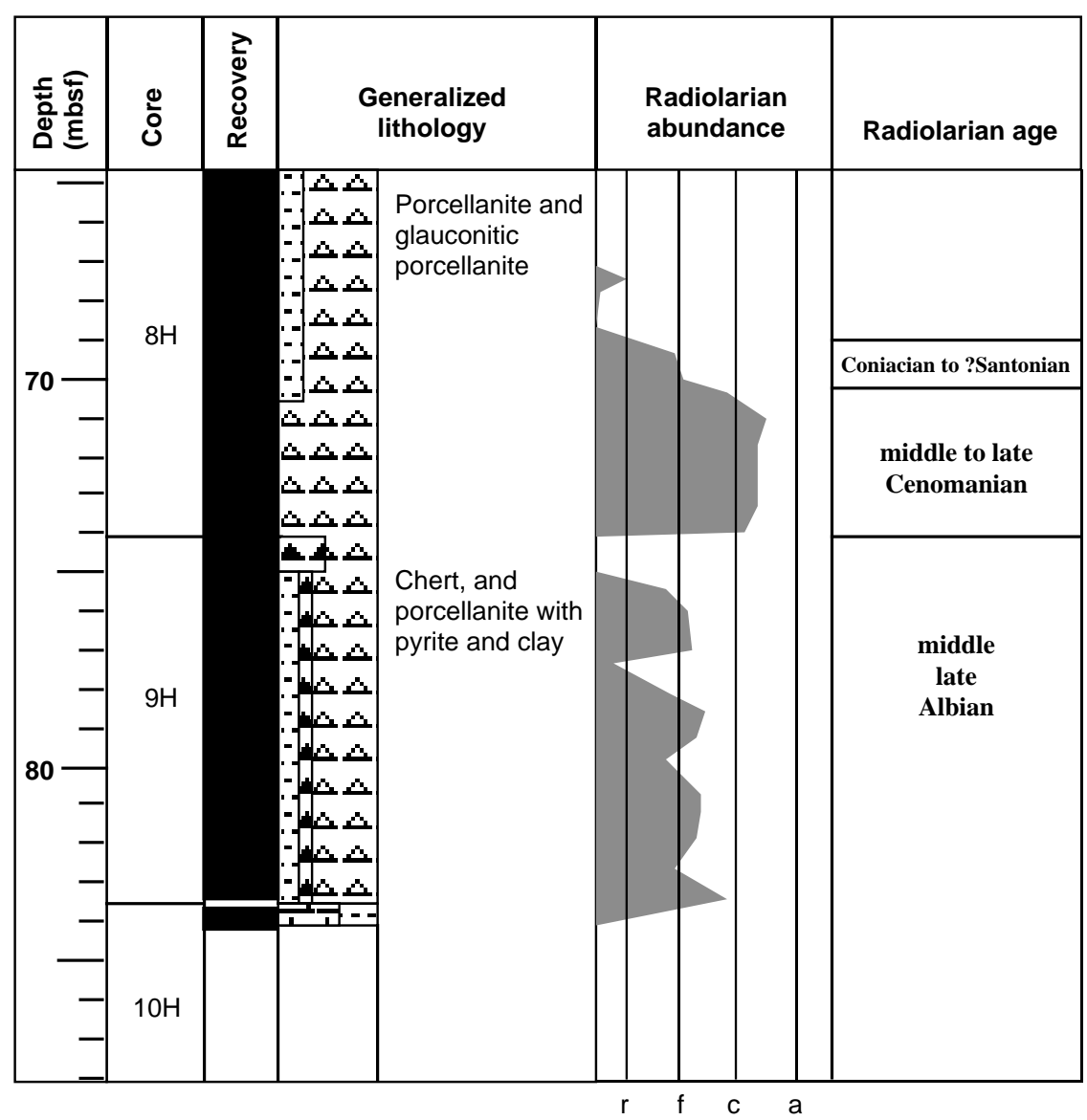

result of the opening of the gateway, are documented from the middle Albian by ammonites and planktonic foraminifers (Wiedmann and Neugebauer, 1978; Moullade et al., 1993). However, recently, Bonatti et al. (1996) documented Berriasian Maiolica-type limestones dated by Calpionellids that resemble Tethyan assemblages. These occurred in the Romanche fracture zone, which lies in the southwestward elongation of Site 962. Even if the paleogeographic position of these limestones remains difficult, it might indicate a first marine ingression within the area of the Equatorial Atlantic Gateway as early as the earliest Cretaceous (Bonatti et al., 1996).

During Leg 159, no marine sediments older then Albian were drilled (Shipboard Scientific Party, 1996). Late Albian to Cenomanian radiolarian faunas are of a remarkably low diversity, compared to time-equivalent assemblages from the Tethys, North Atlantic, and Pacific. Some of the observed species are appearing in a completely different range than described before (Theocampe apicata, Crytamphorella crepida, Cromyodruppa ?concentrica, see taxonomic notes). It is difficult to explain this with an endemism and/or an influence of cold austral water masses. However, an increase of the diversity and average size of the tests in combination with an increase of the number of Tethyan taxa can be observed from Cores 159-962B$8 \mathrm{H}$ through $9 \mathrm{H}$, which can be interpreted as a result of an ongoing opening of the gateway between the North and South Atlantic. Considering the morphotypes at Hole 962B, it is obvious that many elongated nasselarians (e.g., Pseudodictyomitra, Xitus, Novixitus, Torculum, Obeliscoides) as well as most of the hagiastrid spumellarians (Halesium, Patulibracchium, Paronella) are lacking or underrepresented. Forms with a spongy test like Archaespongoprunum, Orbiculiforma, Cavaspongia, Cromyodruppa, and Dactyliosphaera dominate, especially the Cenomanian assemblages. The late Albian is dominated by cryptocephalic nasselarians (e.g., Cryptamphorella).
"Spongy" radiolarians are also an important part of the radiolarian assemblages described from the late Albian and Cenomanian of the Great Valley Sequence in California (Pessagno, 1976, 1977), but are somewhat underrepresented in the Deep Sea Drilling Project (DSDP) sites from the North Atlantic (Thurow, 1988; Erbacher, 1994). Whether this indicates an influence of Pacific faunas and water masses in the South Atlantic remains very questionable. Up to now, too little knowledge about mid-Cretaceous austral assemblages exists to discuss the influences of different faunal provinces on the assemblages of the South Atlantic.

As mentioned above, the percentage of taxa of a clearly Tethyan origin increases toward the late Cretaceous. It would be speculative to discuss the mechanisms of the selection of species migrating into the southern Atlantic. However, if Tethyan forms occur in the eastern equatorial Atlantic, an exchange of Tethyan and South Atlantic water masses must have existed since the late Albian (middle Albian?). A certain degree of endemism could then be explained by a connection of the South Atlantic to Tethyan/North Atlantic water masses at distinct time slices, possibly controlled by sea-level and/or tectonoeustatic movements within the gateway (Shipboard Scientific Party, 1996). Restricted circulation in the equatorial Atlantic basins in times of limited exchange with northern oceans would then lead to endemism. The first observed Tethyan ammonites (Wiedmann and Neugebauer, 1978) and hedbergellids (Moullade et al., 1993) appearing in the South Atlantic are interpreted to be shallow dwellers (Hart, 1980), an argument which would favor the sea-level theory.

Another potential factor responsible for the endemic character of the fauna could be a lower temperature that controlled the absence of many Tethyan taxa in the late Albian. This factor would also explain the limited average size of the late Albian assemblage. Whereas the global temperature gradients toward the Cenomanian/Turonian (e.g., 
Frakes et al., 1992; Barron and Washington, 1984) decreases, the influence of Tethyan elements increases.

It follows that stratigraphic levels at which radiolarians are frequent in the mid-Cretaceous section of Hole 962B correlate well with time-equivalent radiolarian events in other basins (Thurow, 1988; Erbacher and Thurow, 1997). These time intervals are the late Albian (pre-OAE 1d) and the late Cenomanian (pre-OAE 2). Both time intervals are characterized by signs of global sea-level rise and transgressions as well as high abundances and diversities of radiolarians (e.g., Haq et al., 1987; Erbacher et al., 1996). In pelagic environments, the time of highest sea-level/maximum flooding of these transgressive events is represented by black shale levels (so-called oceanic anoxic events; Jenkyns, 1980; Arthur et al., 1990; Erbacher et al., 1996). It is interesting that neither the Vraconian (with OAE 1d) nor the Cenomanian/Turonian Boundary (OAE 2) is recorded in sediments from Hole 962B. This is interpreted as an indication that the paleo-position of Hole 962B lay on a structural high. These hiatuses can be induced by increased bottom currents resulting from the opening of the equatorial gateway, accompanied by changes of circulation patterns. A simple continuing rise of sea level could have similar effects if swell-like structures, which must have existed within the transform system (Shipboard Scientific Party, 1996), played the role of a barrier during times of relatively low sea level.

Another correlation worthy of note is the parallel between radiolarian-rich intervals and the appearance of the clay mineral palygorskite, discussed at length by Pletsch (Chap. 15, this volume).

\section{CONCLUSIONS}

Mid-Cretaceous sediments drilled during ODP Leg 159 reveal three intervals containing radiolarians. These intervals are of ?Coniacian to Santonian (159-962B-8H-4, 2-28 cm), middle to late Cenomanian (159-962B-8H-4, $85 \mathrm{~cm}$, to $8 \mathrm{H}-\mathrm{CC}$ ), and middle late Albian (159-962B-9H to $10 \mathrm{H}-\mathrm{CC}$ ) age. These assemblages are characterized by different preservations, diversities, and average test sizes.

Late Albian to Cenomanian radiolarian faunas show signs of Tethyan faunal influences, but show little diversity. Some of the observed forms differ from relatives from the North Atlantic/Tethys that, together with the small growth of the middle-late Albian fauna and the observed low diversity, are interpreted as signs of endemism. This endemism is discussed as resulting from restricted circulations in the eastern equatorial Atlantic basins and sea-level dependent connection to water masses from the North Atlantic and/or resulting from latitudinal temperature gradients between Tethyan and Austral water masses.

Radiolarian-bearing intervals correlate well with global radiolarian-rich intervals typical for transgressive time periods preceding mid-Cretaceous OAE. Possible hiatuses in the uppermost Albian (Vraconian) and around the Cenomanian/Turonian boundary indicate that the paleo-position of Hole 962B is on a structural high.

\section{ACKNOWLEDGMENTS}

Stimulating discussions and reviews by T. Pletsch, J. Pross, A. Schaaf, J. Thurow, and E. Urquhart are highly appreciated. I thank K. Klose for technical assistance, H. Hüttemann and B. Rödiger for preparing the SEM photos, and W. Hale from the Bremen Core Repository for hospitality and help during core sampling.

\section{REFERENCES}

Arthur, M.A., Brumsack, H.-J., Jenkyns, H.C., and Schlanger, S.O., 1990. Stratigraphy, geochemistry, and paleoceanography of organic carbon-rich
Cretaceous sequences. In Ginsburg, R.N., and Beaudoin, B. (Eds.), Cretaceous Resources, Events and Rhythms: Dordrecht (Kluwer), 75-119.

Barron, E.J., and Washington, W.M., 1984. The role of geographic variables in explaining paleoclimates: results from Cretaceous climate model sensitivity studies. J. Geophys. Res., 89:1267-1279.

Basile, C., Mascle, J., Sage, F., Lamarche, G., and Pontoise, B., 1996. Precruise and site surveys: a synthesis of marine geological and geophysical data on the Côte d'Ivoire-Ghana Transform Margin. In Mascle, J., Lohmann, G.P., Clift, P.D., et al., Proc. ODP, Init. Repts., 159: College Station, TX (Ocean Drilling Program), 47-60.

Baumgartner, P.O., 1980. Late Jurassic Hagiastridae and Patulibracchiidae (Radiolaria) from the Argolis Peninsula (Peleponnesus, Greece). Micropaleontology, 26:274-322.

Bonatti, E., Ligi, M., Borsetti, A.M., Gasperini, L., Negri, A., and Sartori, R., 1996. Lower Cretaceous deposits trapped near the equatorial Mid-Atlantic Ridge. Nature, 380:518-520.

Campbell, A.S., and Clark, B.L., 1944. Radiolaria from Upper Cretaceous of middle California. Spec. Pap.-Geol. Soc. Am., 57:1-61.

Dumitrica, P., 1970. Cryptocephalic and cryptothoracic Nassellaria in some Mesozoic deposits of Romania. Rev. Roumaine Geol. Geophys. Geogr., Ser. Geol., 14:45-124.

Ellis, G., 1993. Late Aptian-Early Albian radiolaria of the Windalia Radiolarite (type section), Carnarvon Basin, Western Australia. Eclogae Geol. Helv., 86:943-995.

Empson-Morin, K., 1981. Campanian Radiolaria from DSDP Site 313, MidPacific Mountains. Micropaleontology, 27:249-292.

Erbacher, J., 1994. Entwicklung und Paläoozeanographie mittelkretazischer Radiolarien der westlichen Tethys (Italien) und des Nordatlantiks. Tubing. Mikropalaontol. Mitteil., 12:1-120.

Erbacher, J., and Thurow, J., 1997. Influence of oceanic anoxic events on the evolution of mid-Cretaceous radiolaria in the North Atlantic and western Tethys. Mar. Micropalaeontol., 30:139-158.

Erbacher, J., and Thurow, J., in press. Mid-Cretaceous radiolarian zonation for the North Atlantic - an example of oceanographically controlled evolutionary processes in the marine biosphere? Geol. Soc. London, Spec. Publ., 131.

Erbacher, J., Thurow, J., and Littke, R., 1996. Evolution patterns of radiolaria and organic matter variations: a new approach to identify sea-level changes in mid-Cretaceous pelagic environments. Geology, 24:499-502.

Foreman, H.P., 1968. Late Maastrichtian radiolaria of California. Spec. Pap. Paleontol., 3:1-82.

, 1971. Cretaceous radiolaria, Leg 7, DSDP. In Winterer, E.L., Riedel, W.R., et al., Init. Repts. DSDP, 7: Washington (U.S. Govt. Printing Office), 1673-1693.

, 1973. Radiolaria of Leg 10 with systematics and ranges for the families Amphipyndacidae, Artostrobiidae, and Theoperidae. In Worzel, J.L., Bryant, W., et al., Init. Repts. DSDP, 10: Washington (U.S. Govt. Printing Office), 407-474.

, 1978. Cretaceous radiolaria in the eastern South Atlantic, Deep Sea Drilling Project, Leg 40. In Bolli, H.M., Ryan, W.B.F., et al., Init. Repts. DSDP, 40: Washington (U.S. Govt. Printing Office), 839-843.

Frakes, L.A., Francis, J.E., and Syktus, J.I., 1992. Climate Modes of the Phanerozoic: Cambridge (Cambridge Univ. Press).

Haq, B.U., Hardenbol, J., and Vail, P.R., 1987. Chronology of fluctuating sea levels since the Triassic. Science, 235:1156-1167.

Hart, M.B., 1980. A water depth model for the evolution of the planktonic Foraminiferida. Nature, 286:252-254.

Jenkyns, H.C., 1980. Cretaceous anoxic events: from continents to oceans. J. Geol. Soc. London, 137:171-188.

Ling, H.Y., and Lazarus, D.B., 1990. Cretaceous radiolaria from the Weddell Sea: Leg 113 of the Ocean Drilling Program. In Barker, P.F., Kennett, J.P., et al., Proc. ODP, Sci. Results, 113: College Station, TX (Ocean Drilling Program), 353-363.

Moullade, M., Mascle, J., Benkhelil, J., Cousin, M., and Tricart, P., 1993. Occurrence of marine mid-cretaceous sediments along the Guinean slope (Equamarge II cruise): their significance for the evolution of the central Atlantic African margin. Mar. Geol., 110:63-72.

O’Dogherty, L., 1994. Biochronology and paleontology of middle Cretaceous radiolarians from Umbria-Marche Appennines (Italy) and Betic Cordillera (Spain). Mem. Geol. Lausanne, 21:1-351.

Pessagno, E.A., 1963. Upper Cretaceous Radiolaria from Puerto Rico. Micropaleontology, 9:197-214. 
1971. Jurassic and Cretaceous Hagiastridae from the BlakeBahama Basin (Site 5A, JOIDES Leg 1) and the Great Valley Sequence, California Coast Ranges. Bull. Am. Paleontol., 60:5-83.

, 1972. Cretaceous radiolaria. Part 1. The Phaseliformidae, new family, and other Spongodiscacea from the Upper Cretaceous portion of the Great Valley Sequence. Part 2: Pseudoaulophacidae Riedel from the Cretaceous of California and the Blake-Bahama Basin (Joides Leg 1). Bull. Am. Paleontol., 61:263-368.

, 1973. Late Cretaceous Spumellariina from the Great Valley Sequence, California Coast Ranges. Bull. Am. Paleontol., 63:49-102.

— 1976 . Radiolarian zonation and stratigraphy of the Late Cretaceous portion of the Great Valley Sequence, California Coast Range. Micropaleontology, Spec. Publ., 2:1-95.

_ 1977. Lower Cretaceous Radiolarian biostratigraphy of the Great Valley sequence and Franciscan Complex, California Coast Ranges. Spec. Publ. Cushman Found. Foram. Res., 15:5-87.

Schaaf, A., 1984. Les radiolaires du Cretace Inferiuer et Moyen: biologie et systematiques. Sci. Geol. Mem., 75:1-189.

Shipboard Scientific Party, 1996. Principal results. In Mascle, J., Lohmann, G.P., Clift, P.D., et al., Proc. ODP, Init. Repts., 159: College Station, TX (Ocean Drilling Program), 297-314.

Squinabol, S., 1903. Le Radiolaire dei noduli selciosi nella Scaglia degli Euganei. Contribuzione I (Radiolaria from siliceous nodules of the Euganei shales). Riv. Ital. Paleontol., 9:105-151.

Thurow, J., 1988. Cretaceous radiolarians of the North Atlantic Ocean: ODP Leg 103 (Sites 638, 640, and 641) and DSDP Legs 93 (Site 603) and 47B (Site 398). In Boillot, G., Winterer, E.L., et al., Proc. ODP, Sci. Results, 103: College Station, TX (Ocean Drilling Program), 379-418.

Wiedmann, J., and Neugebauer, J., 1978. Lower Cretaceous ammonites from the South Atlantic Leg 40 (DSDP), their stratigraphic value and sedimentologic properties. In Bolli, H.M., Ryan, W.B.F., et al., Init. Repts. DSDP, 40: Washington (U.S. Govt. Printing Office), 709-734.

\section{Date of initial receipt: 16 September 1996 \\ Date of acceptance: 2 January 1997 \\ Ms 159SR-037}

\section{APPENDIX}

\section{Taxonomic Notes}

Radiolarians are listed in alphabetic order. The listed references refer to either the original and/or other relevant descriptions of the described species. Where appropriate, an explanatory text and the stratigraphic range of the taxa are added. See O'Dogherty (1994) or Erbacher (1994) for more complete synonyms and reference list.

\section{Acaeniotyle diaphorogona (Foreman)}

Acaeniotyle diaphorogona Foreman, 1973, p. 258, pl. 2, figs. 2-5.

A. diaphorogona has been described from the Early Cretaceous to early Turonian, worldwide.

$$
\text { Acaeniotyle amplissima (Foreman) }
$$

Acaeniotyle florea, Ozvoldova and Petercakova, Erbacher, 1994, p. 90, pl. 11, fig. 10.

Acaeniotyle amplissima (Foreman), O’Dogherty, 1994, pp. 288-289, pl. 51, figs $11-14$.

A. amplissima has been described from the Aptian to early Turonian of the North Atlantic and western Tethys.

$$
\text { Acaeniotyle umbilicata (Rüst) }
$$

(P1. 2, Fig. 19)

Acaeniotyle umbilicata (Rüst), Foreman, 1973, p. 258, pl. 1, figs. 13, 14, 16.

Acaeniotyle with two polar spines. The strongly developed tubercles and short spines lead me to place this form into A. umbilicata (see discussion in O’Dogherty, 1994)
Acanthocircus aff. multidentatus? (Squinabol)

(P1. 2, Fig. 22)

Acanthocircus multidentatus (Squinabol), Pessagno, 1977, p. 32, pl. 3, figs. 15, 20; O’Dogherty, 1994, p. 255, pl. 44, figs. 7-10.

Since only fragments have been observed in samples of Hole 962B, a clear placement of these forms to A. multidentatus is questionable. The range of this form is not well established, mid-Cretaceous.

\section{Alievum sculptus (Squinabol)}

$$
\text { (P1. 2, Fig. 16) }
$$

Alievium antiquum, Pessagno, 1972, p. 298, pl. 24, figs. 1-4; Erbacher, 1994, pp. 90-91, pl.12, fig. 1.

Pseudoaulophacus sculptus (Squinabol), O’Dogherty, 1994, pp. 319-320, pl. 59, figs. $1-4$

A sculptus has been recorded from the middle Albian to Cenomanian of the Central Pacific, California, North Atlantic, and Central Italy.

\section{Angulobracchia digita (Baumgartner)}

$$
\text { (Pl. 2, Fig. 27) }
$$

Angulobracchia digita, Baumgartner, 1980, pp. 310-312, pl. 10, figs. 18-22, pl. 12, fig. 11; Erbacher, 1994, p. 92, pl. 5, figs. 5 and 6 .

Only one single specimen was observed in Sample 159-962B-8H-6, 137$141 \mathrm{~cm}$. A. digita has been described from the Middle to Late Jurassic of Greece (Baumgartner, 1980) and the early late Albian of the North Atlantic (Erbacher, 1994)

$$
\text { Archaeodictyomitra crebrisulcata (Squinabol) }
$$

(Pl. 1, Fig. 10)

Dictyomitra crebrisulcata (Squinabol), O’Dogherty, 1994, p. 75, pl. 2, figs. $12-17$.

D. crebrisulcata has been recorded from the middle Cenomanian to lowermost Turonian of Central Italy.

\section{Archaeodictyomitra simplex Pessagno}

(P1. 1, Fig. 11)

Archaeodictyomitra simplex, Pessagno, 1977, p. 43, pl. 6, figs. 1, 24, 28, pl. 12, fig. 12; Thurow, 1988, p. 398, pl. 3, fig. 9.

Dictyomitra montisserei (Squinabol), O’Dogherty, 1994, p. 77, pl. 3, figs. 129

\section{Archaeospongoprunum carrierensis (Pessagno)}

$$
\text { (P1. 1, Fig. 22) }
$$

Archaeospongoprunum carrierensis, Pessagno, 1977, p. 29, pl. 1, figs. 6, 7, 9; Ellis, 1993 , p. 958 , pl. 3, figs. 3,4

Recorded from the late Aptian to late Albian of Western Australia and California. The range of this form is not yet well established.

\section{Archaeospongoprunum sp. \\ (P1. 1, Figs. 23 and 29)}

These forms, common in Albian and Cenomanian samples of Hole 962B, have an elongated, cylindrical test. One spine is triradiate, the other spiral. They resemble A. triplum (Pessagno, 1973) but lack distinct lobes. A. triplum has been described from the Coniacian of California.

$$
\text { Cavaspongia euganea (Squinabol) }
$$

$$
\text { (P1. 2, Fig. 24) }
$$

Dumitricaia sp. EJ 1, Erbacher, 1994, p. 98, pl. 12, fig. 6. Dumitricaia sp. EJ 2, Erbacher, 1994, p. 98, pl. 12, fig. 5.

Cavaspongia euganea (Squinabol), O’Dogherty, 1994, p. 309, pl. 56, figs. 8 14. 
The known range of $C$. euganea is late Albian to late Cenomanian (?early Turonian). The central part of the forms illustrated herein is less raised then with those from Central Italy.

\section{Cavaspongia sphaerica O’Dogherty}

(P1. 2, Fig. 23)

Cavaspongia sphaerica, O’Dogherty, 1994, p. 311, pl. 57, figs 1-7.

C. spaerica is a common part of the assemblages from interval 159-962B$8 \mathrm{H}-4,85 \mathrm{~cm}$, through $8 \mathrm{H}-\mathrm{CC}$. A single specimen was observed in interval 159-962B-9H-2, 88-92 cm. The taxon has been described from the late Albian to Turonian of Central Italy. The forms observed in Core 159-962B-8H differ from those described by O'Dogherty (1994) in possessing a more inflated central area.

\section{Cromyodruppa ? concentrica Lipmann} (Pl. 2, Figs. 14-15)

Cromyodruppa ? concentrica Lipmann, Ling and Lazarus, 1990, p. 355, pl. 1, figs. $11-13$

This spongy species is one of the most common throughout all cores bearing Albian to Cenomanian radiolaria of Hole 962B. C. ? concentrica has been described from the Campanian to Maastrichtian of the Central Atlantic, Weddell Sea and Russia, but is of a late Albian age in the section examined herein.

\section{Crucella irwini Pessagno}

(P1. 2, Fig. 29)

Crucella irwini, Pessagno, 1971, p. 55, pl. 9, figs. 4-6; Erbacher, 1994, p. 96, pl. 18, fig. 5; O’Dogherty, 1994, p. 369, pl. 71, figs. 7-14.

C. irwini has been reported from Cenomanian to Turonian strata, worldwide.

\section{Crucella messinae Pessagno}

(Pl. 2, Fig. 26)

Crucella messinae, Pessagno, 1971, p. 56, pl. 6, figs. 1-3.

Cryptamphorella conara (Foreman)

(Pl. 2, Figs. 10-11)

Hemicryptocapsa conara, Foreman, 1968, p. 35, pl. 4, figs. 11a, b

Cryptamphorella conara (Foreman), (Dumitrica, 1970), p. 80, pl. 11, figs.

66a-c; 1972, p. 842, pl. 1, figs. 2-5; 1975, fig. 2, no. 28; Erbacher, 1994,

p. 97 , pl. 5 , fig. 7 .

\section{Cryptamphorella crepida O’Dogherty}

(Pl. 2, Fig. 13)

Cryptamphorella crepida, O’Dogherty, 1994, p. 210, pl. 34, figs. 15-21.

The range of $C$. crepida has been described as early to middle Aptian (O'Dogherty, 1994) and has been described from the Pacific, North Atlantic and western Tethys. However, this form appears in the late Albian of Hole 962B which might again be a sign of endemism.

\section{Cryptamphorella $\mathrm{sp}$}

(Pl. 2, Fig. 12)

This cryptothoracic form possesses a small elevated cephalis. The cephalis is perforate. No sutural pore was preserved on the very few observed specimens. Abdominal wall thickened by nodes. Nodes are connected by crests, building polygonal areas.

\section{Dactyliosphaera silviae Squinabol}

(Pl. 1, Fig. 27)

Pseudoaulophacus ? sp. D, Thurow, 1988, p. 404, pl. 5, fig. 14; Erbacher, 1994 , p. 109 , pl. 12 , fig. 13 , pl. 16, fig. 14.

Dactyliosphaera silviae Squinabol, O’Dogherty, 1994, p. 341, pl. 63, figs. 22-26.
D. silviae is the nominal species of O'Dogherty's (1994) Silviae-Zone, ranging from late early Cenomanian to late Cenomanian. However, this form has been described from middle Albian to Cenomanian sediments of the North Atlantic (see Erbacher, 1994).

\section{Dactyliosphaera lepta (Foreman)} (Pl. 1, Fig. 28)

Amphibrachium leptum, Foreman, 1978, p. 841, pl. 1, figs. 8 and 9. ? Spongodruppa sp. EJ 1, Erbacher, 1994, p. 113, pl. 13, fig. 3. Dactyliosphaera lepta, O’Dogherty, 1994, p. 340, pl. 63, figs. 13-21

D. lepta is one of the characteristic forms of interval 159-962B-8H-4, 85 $\mathrm{cm}$, to $8 \mathrm{H}-\mathrm{CC}$. The species has been described from the late Albian to early late Cenomanian of Central Italy and the North and South Atlantic. Compared to Tethyan occurrences, D. lepta in the material investigated herein lacks a well-developed rise of the central cavity.

\section{Dicroa rara (Squinabol)}

(Pl. 2, Fig. 18)

Dicroa rara (Squinabol), O’Dogherty, 1994, pp. 281-282, pl. 49, figs. 26-30.

This species has been described from the late Albian to lowermost Turonian of the western Tethys.

\section{Dictyomitra densicostata Pessagno}

$$
\text { (Pl. 1, Fig. 4) }
$$

Dictyomitra densicostata, Pessagno, 1976, p. 51, pl. 14, figs. 10-14, 16.

This form has been described from the Campanian of California.

\section{Dictyomitra multicostata Zittel}

$$
\text { (P1. 1, Fig. 5) }
$$

Dictyomitra multicostata Zittel, O’Dogherty, 1994, p. 82, pl. 4, figs. 17-19.

D. multicostata has been described from early Turonian to Campanian (Maestrichtian?), worldwide.

\section{Dictyomitra napaensis Pessagno}

(P1. 1, Fig. 3)

Dictyomitra napaensis, Pessagno, 1976, p. 53, pl. 4, fig. 16, pl. 5, figs. 1, 9.

D. napaensis has been described from the late Turonian to late Coniacian of California.

Guttacapsa biacuta (Squinabol)

(Pl. 1, Fig. 15)

Guttacapsa biacuta (Squinabol), O'Dogherty, 1994, p. 226, pl. 37, figs. 3135 .

G. biacuta is the nominal species of the biacuta subzone (O'Dogherty, 1994), uppermost Cenomanian of Central Italy.

Guttacapsa gutta (Squinabol)

$$
\text { (Pl. 1, Fig. 8) }
$$

Guttacapsa gutta (Squinabol), O’Dogherty, 1994, pl. 38, figs. 1-6. G. gutta has been described from the late Cenomanian of Central Italy and Japan.

\section{? Hiscocapsa sp.}

(P1. 1, Figs. 19-20)

This form is a common part of the Cenomanian assemblage of the investigated core. As any ornamentation on the large globose, open, terminal chamber is lacking, this form is only tentatively placed within the genus Hiscocapsa. The examined forms lack an apical horn; their cephalis is small, smooth, and round. The distal chamber possesses an aperture. 
?Krempelinella $\mathrm{sp}$.

(Pl. 1, Fig. 7)

The genus Krempelinella has been defined by Empson-Morin (1981). Following her, Krempelinella resembles Neosciadiocapsidae and is closely related to the genus Rhopalosyringium.

The type species of this genus $K$. kronenartiga has been described from the Campanian of the Central Pacific.

\section{Mita gracilis (Squinabol)}

(Pl. 1, Fig. 13)

Mita gracilis (Squinabol), Thurow, 1988, p. 402, pl. 3, fig. 2., Erbacher, 1994, p. 102, figs. 10 and 11.

Dictyomitra gracilis (Squinabol), O’Dogherty, 1994, p. 73, pl. 1, figs. 12-25.

M. gracilis has been described from the Albian to early late Cenomanian worldwide.

\section{Napora praespinifera (Pessagno)}

(Pl. 1, Fig. 21)

Napora praespinifera, Thurow, 1988, p. 402, pl. 5, fig. 3, Erbacher, 1994, p. 103, pl. 9, fig. 8, pl. 13, fig. 8 .

Ultranapora praespinifera Pessagno, 1977, p. 39, pl. 5, figs. 4, 8-10, O’Dogherty, 1994, p. 241, pl. 41, figs. 15-23.

Novixitus mclaughlini Pessagno

(Pl. 2, Fig. 6)

Novixitus mclaughlini, Pessagno, 1977, p. 54, pl. 9, fig. 17; Thurow, 1988, p. 402, pl. 3, fig. 21; Erbacher, 1994, p. 104, pl. 6, fig. 4, pl. 7, figs. 13-14.

This species has been recorded from the Albian to Cenomanian of California, North Atlantic and western Tethys.

\section{Orbiculiforma maxima Pessagno}

(Pl. 1, Fig. 25)

Orbiculiforma maxima, Pessagno, 1976, pp. 34-35, pl. 1, fig. 14, 16

Orbiculiforma railensis Pessagno, Thurow, 1988, p. 403, pl. 5, fig. 18.

Orbiculiforma sp. EJ2, Erbacher, 1994, p. 105, pl. 2, figs. 7-8

Dactyliosphaera maxima (Pessagno), O’Dogherty, 1994, pp. 338-339, pl. 63, figs. 5-8.

non Orbiculiforma maxima Pessagno, Erbacher, 1994, pp. 104-105, pl. 13, figs. 5-6.

O. maxima has been described from the late Aptian to Cenomanian of Central Italy, North Atlantic, California, and Pacific.

\section{Orbiculiforma sp.}

(Pl. 2, Fig. 17)

This form is a common part of radiolarian assemblages from the late Albian of the investigated core.

\section{Patellula heroica O'Dogherty}

(Pl. 1, Fig. 26)

Patellula heroica, O’Dogherty, 1994, p. 330, pl. 61, figs. 6-11.

P. heroica has been described from the early Turonian of Central Italy.

\section{Patellula verteroensis (Pessagno)}

(Pl. 1, Fig. 24)

Stylospongia verteroensis Pessagno, 1963, p. 199, pl. 3, figs. 1-3, pl. 6, figs. 2,3 , pl. 7, figs. 3,6

Patellula verteroensis, Erbacher, 1994, p. 106, pl. 19, figs. 1-2; O’Dogherty, 1994 , pp. 328-329, pl. 60, figs. 25-26.

P. verteroensis has been described worldwide from the late Cenomanian to Campanian.
Patulibracchium sp.

(Pl. 2, Fig. 25)

As only one to two rays are preserved in the forms examined in this study; a clear identification of these forms on a species level is impossible. Hagiastrid radiolarians are remarkably rare in Cretaceous faunas from Hole 962B.

\section{Pseudodictyomitra lodogaensis Pessagno}

(Pl. 2, Fig. 4)

Pseudodictyomitra lodogaensis, Pessagno, 1977, p. 50, pl. 8, figs. 4, 21, 28;

Ellis, 1993, p. 969, pl. 4, fig. 18; Erbacher, 1994, pp. 109-110, pl. 8, figs.

1-2, O’Dogherty, 1994, pp. 103-104, pl. 7, figs. 18-21.

This form has been reported from the late Aptian to late Albian, worldwide.

\section{Rhopalosyringium hispidum O'Dogherty}

(Pl. 1, Fig. 6)

Rhopalosyringium hispidum, O’Dogherty, 1994, p. 167, pl. 23, figs. 7-11.

R. hispidum has been described from the early Turonian of Central Italy.

\section{Rhopalosyringium mosquense (Smirnova and Aliev)}

$$
\text { (P1. 2, Fig. 8) }
$$

Rhopalosyringium majuroensis Schaaf, Thurow, 1988, p. 405, pl. 4, fig. 15.; Erbacher, 1994, p. 111, pl. 9, fig. 5.

Rhopalosyringium mosquense (Smirnova and Aliev), O'Dogherty, 1994, pp. 165-166, pl. 22, figs. 1-6.

R. mosquense has been described from the late Albian of the North Atlantic and late Albian to late Cenomanian of the western Tethys.

$$
\text { Rhopalosyringium sp. cf. R. euganeum (Squinabol) }
$$$$
\text { (Pl. 1, Fig. 18) }
$$

The form described herein differs from $R$. euganeum, illustrated in O'Dogherty (1994) and as Rhopalosyringium sp. C in Thurow (1988) and Erbacher (1994), by lacking an apical horn, by lacking clear strictures, and by being more slender. $R$. aff. $R$. euganeum is rare but occurs in every sample that has been investigated of interval 159-962B-8H-4, $85 \mathrm{~cm}$, through $8 \mathrm{H}-\mathrm{CC}$, as well as in some samples of Cores 159-962B-9H through $10 \mathrm{H}$.

$$
\text { Savaryella quadra (Foreman) }
$$

$$
\text { (Pl. 2, Fig. 28) }
$$

Crucella quadra, Foreman, 1978, p. 841, pl. 1, fig. 10. Savaryella quadra (Foreman), O'Dogherty, 1994, p. 372, pl. 72, figs. 1-11.

S. quadra has been recorded from the late Albian to middle Cenomanian of the South Atlantic and Central Italy.

\section{Stichomitra communis Squinabol}

$$
\text { (Pl. 1, Fig. 12) }
$$

Stichomitra communis, Squinabol, 1903, p. 141, pl. 8, fig. 40.

This common species has been reported from the late Aptian to Turonian, worldwide.

$$
\text { Stichomitra stocki (Campbell and Clark) }
$$

(Pl. 1, Fig. 14, Pl. 2, Fig. 1)

Stichocapsa (?) stocki, Campbell and Clark, 1944, p. 44, pl. 8, figs. 31-33. Amphipyndax stocki (Campbell and Clark), Foreman, 1968, p. 78, pl. 8, figs. $12 \mathrm{a}-\mathrm{c}$.

Amphipyndax mediocris (Tan Sin Hok), Erbacher, 1994, pp. 91-92, pl. 6, figs. $1-2$.

Stichomitra stocki (Campbell and Clark), O’Dogherty, 1994, pp. 147-148, pl. 18, figs. 9-15. 
Stichomitra stocki has been described from the middle Cenomanian to Campanian almost worldwide. The confusion about former Amphipyndax stocki and A. mediocris has been cleared by O'Dogherty (1994) who observed that both forms are homeomorph, but clearly separated by a disconnected stratigraphic range at least in the Central Italian sections he examined. However, the late Albian forms of $S$. stocki as illustrated herein (Pl. 1, Fig. 14, and Pl. 2, Fig. 1) clearly resemble O'Dogherty's (1994) S. stocki even that they appear in the late Albian, which should be after O'Dogherty (1994) within the range of $S$. mediocris

\section{Theocampe apicata Foreman}

\section{(Pl. 2, Fig. 5}

Theocampe apicata, Foreman, 1971, p. 1679, pl. 4, fig. 6; Empson-Morin, 1981, p. 262, pl. 7, figs. 1a-2d.

This tiny species appears in two samples of Core 159-962B-9H. To my knowledge it has not been described from sediments older then Campanian, but is of a late Albian age in the section examined herein.

\section{Torculum coronatum (Squinabol)}

$$
\text { (Pl. 1, Fig. 17) }
$$

Theoconus coronatus Squinabol group, Erbacher, 1994, p. 116, pl. 7, fig. 6, pl. 14, figs. 4-5, pl. 15, figs. 12-13.

Theoconus spp. group, Erbacher, 1994, p. 116, pl. 7, figs. 7-10, pl. 14, fig. 6. Torculum coronatum (Squinabol), O'Dogherty, 1994, p. 133, pl. 12, figs. 27-

28, pl. 14, figs. 1-29.

This species is of a incredible morphological variance. It ranges from the middle Albian to early late Cenomanian and has been described worldwide.

\section{Tubilustrium sp. aff. T. transmontanum O’Dogherty}

(Pl. 1, Fig. 16)

The described specimens lack the strongly compressed distal chamber of T. transmontanum (see O'Dogherty, 1994). T. transmontanum has been described from the late Albian to late Cenomanian of Central Italy.

\section{Triactoma $\mathrm{sp}$}

$$
\text { (Pl. 2, Fig. 20) }
$$

This morphotype is rather frequent in almost all "Cenomanian" samples of the investigated core.

\section{Vitorfus morini Empson-Morin}

(Pl. 1, Fig. 9)
Vitorfus morini, Empson-Morin, 1981, p. 261, pl. 4, figs. 7a-8d, O’Dogherty, 1994 , pp. 267-268, pl. 47, figs. 12-15.

The specimen illustrated herein is rather poorly preserved. However, the spines are only bladed in the proximal parts and, therefore, clearly separate this form from the genus Archaeospongoprunum. V. morini has been described from the early Turonian to Campanian of Central Italy, the Pacific, and Japan.

\section{Xitus spicularius (Aliev)}

(P1. 1, Figs. 1-2)

Xitus spicularius (Aliev) - Pessagno, 1977, p. 56, pl. 9, fig. 7, pl. 10, fig. 5; Erbacher, 1994, p. 118, pl. 3, fig. 4, pl. 15, fig. 7; O’Dogherty, 1994, p. 127 , pl. 11, figs. 17-31.

X. spicularius has been described from late Aptian to late Cenomanian deposits, worldwide. At Hole 962B, this species only appears in interval 159962B-8H-4, 24-28 cm, which seems to be of a late Turonian to Santonian age. This form has also been observed in the Campanian of Cyprus (E. Urquhart, pers. comm., 1996).

\section{Xitus spinosus (Squinabol)}

$$
\text { (P1. 2, Fig. 3) }
$$

Xitus spinosus (Squinabol), O’Dogherty, 1994, pp. 129-130, pl. 12, figs. 113

\section{?Xitus sp. cf. X. spicularius}

$$
\text { (Pl. 2, Fig. 2) }
$$

This form is common in samples of Cores 159-962B-9H and $10 \mathrm{H}$. It differs from $X$. spicularius by lacking the outer layer and therefore only showing the inner layer with small uniform pore frames. Most of the observed specimens have less then five post abdominal chambers. As the forms examined herein resemble a specimen of X. spicularius illustrated in O'Dogherty, 1994 (pl. 11, fig. 23) they have tentatively been placed within this species. This species is considered as another sign for endemism in the late Albian of the Eastern Equatorial Atlantic.

$$
\text { gen. et sp. indet } 1
$$

(P1. 2, Fig. 7)

A rare, tiny species that has only been observed in two samples of Cores $159-962 \mathrm{~B}-9 \mathrm{H}$ and $10 \mathrm{H}$. 

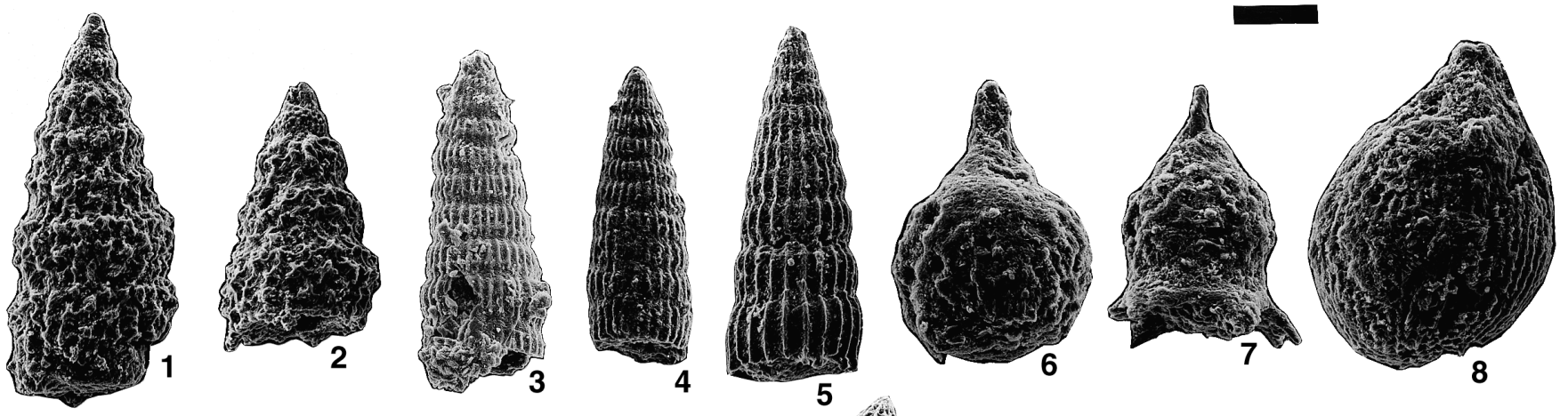
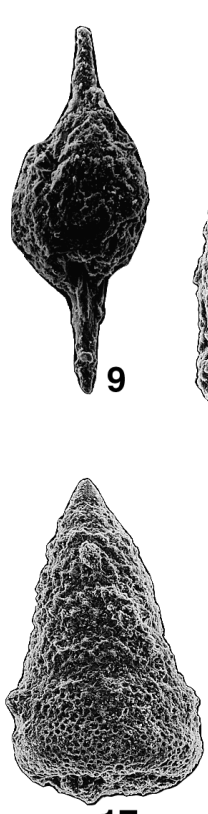

17

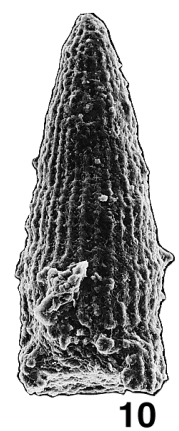

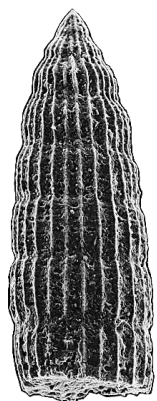

11

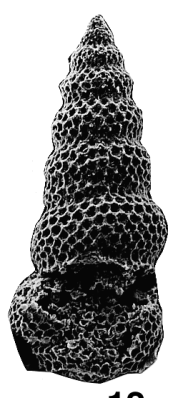

12

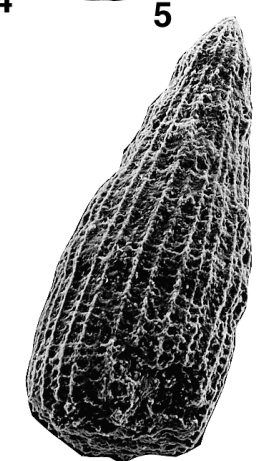

13
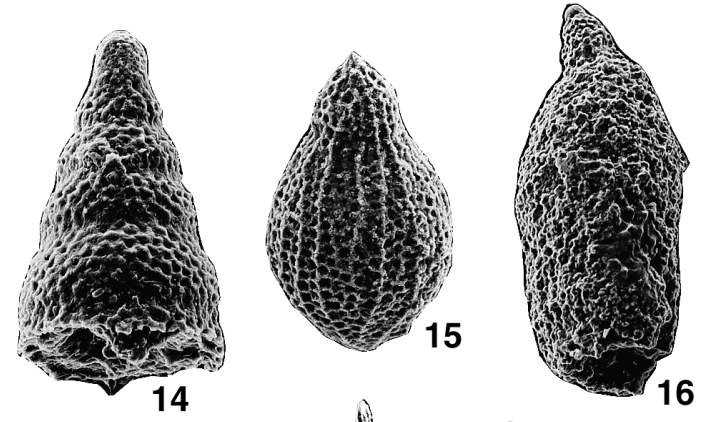

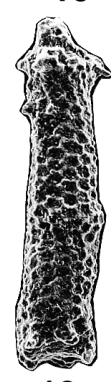

18

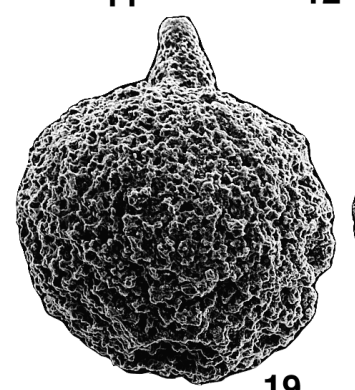

19

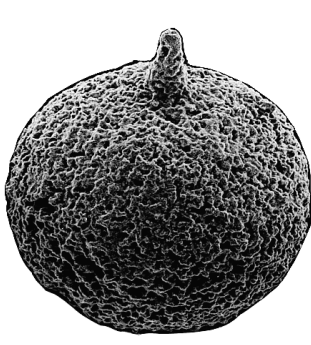

20

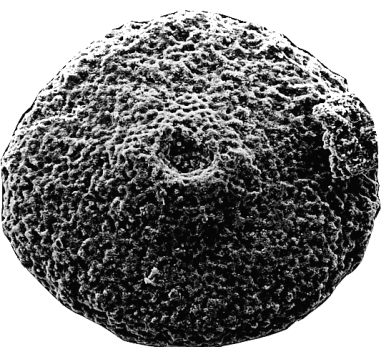

24

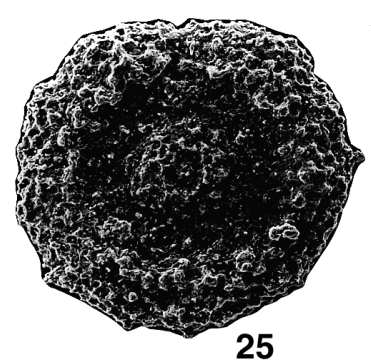

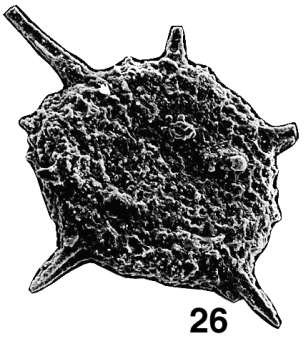

26

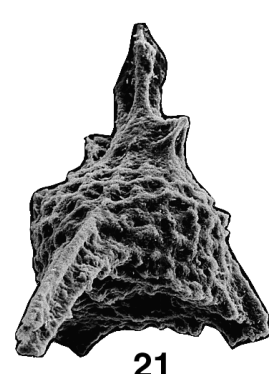

21
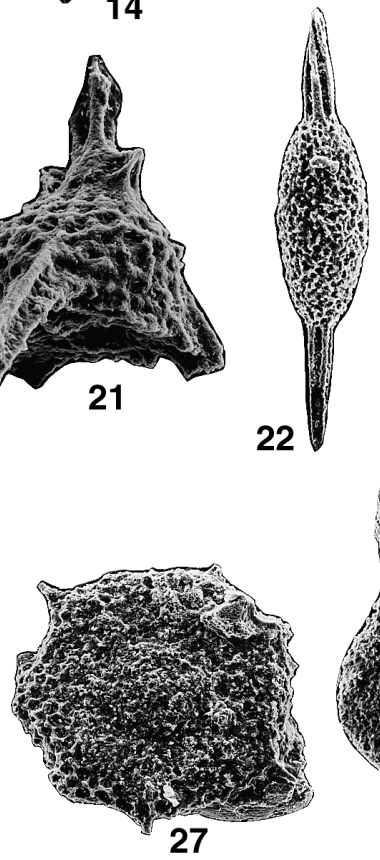

Plate 1. Scale bar $=40 \mu \mathrm{m}$ for Figures 10, 14, 6, and 21; $50 \mu \mathrm{m}$ for Figures 8, 29, 7, and 15; 65 $\mu \mathrm{m}$ for Figures 3, 26, 4, 1, 2, 13, and 9; 100 $\mu \mathrm{m}$ for Figures 27, $11,25,28,23,18,5,22,12,16,20,24$, and 19; and $200 \mu \mathrm{m}$ for Figure 17. Specimens illustrated in plate Figures 1 through 9 are from Sample 159-962B-8H-4, 24-28 cm. 1, 2. Xitus spicularius. 3. Dictyomitra napaensis. 4. Dictyomitra densicostata. 5. Dictyomitra multicostata. 6. Rhopalosyringium hispidum. 7. ?Krempelinella sp. 8. Guttacapsa gutta. 9. Vitorfus morini. 10. Archaeodictyomitra crebrisulcata Sample 159-962B-8H-4, 85-86 cm. 11. Archaeodictyomitra simplex Sample 159-962B-8H-5, 65-69 cm. 12. Stichomitra communis Sample 159-962B-8H-6, 137-141 cm. 13. Mita gracilis Sample 159-962B-8H-6, 137-141 cm. 14. Stichomitra stocki Sample 159-962B-8H-4, 85-86 cm. 15. Guttacapsa biacuta Sample 159-962B-8H-6, 137-141 cm. 16. Tubilastrum sp. aff. T. transmontanum Sample 159-962B-8H-6, 137-141 cm. 17. Torculum coronatum Sample 159-962B-8H-5, 65-69 cm. 18. Rhopalosyringium sp. (cf. R. euganeum) Sample 159-962B-8H-CC, 14-16 cm. 19, 20. ? Hiscocapsa sp. Sample 159-962B-8H-6, 137-141 cm. 21. Napora praespinifera Sample 159-962B-8H-6, 137-141 cm. 22. Archaeospongoprunum carrierensis Sample 159-962B-8H-CC, 14-16 cm. 23. Archaeospongoprunum sp. Sample 159-962B-8H-CC, 14-16 cm. 24. Patellula verteroensis Sample 159-962B-8H-6, 137-141 cm. 25. Orbiculiforma maxima Sample 159-962B-8H-6, 137-141 cm. 26. Patellula heroica Sample 159962B-8H-6, 137-141 cm. 27. Dactyliosphaera silviae Sample 159-962B-8H-5, 34-36 cm. 28. Dactyliosphaera lepta Sample 159-962B-8H-6, $137-141$ cm. 29. Archaeospongoprunum sp. Sample 159-962B-8H-6, 137-141 cm. 

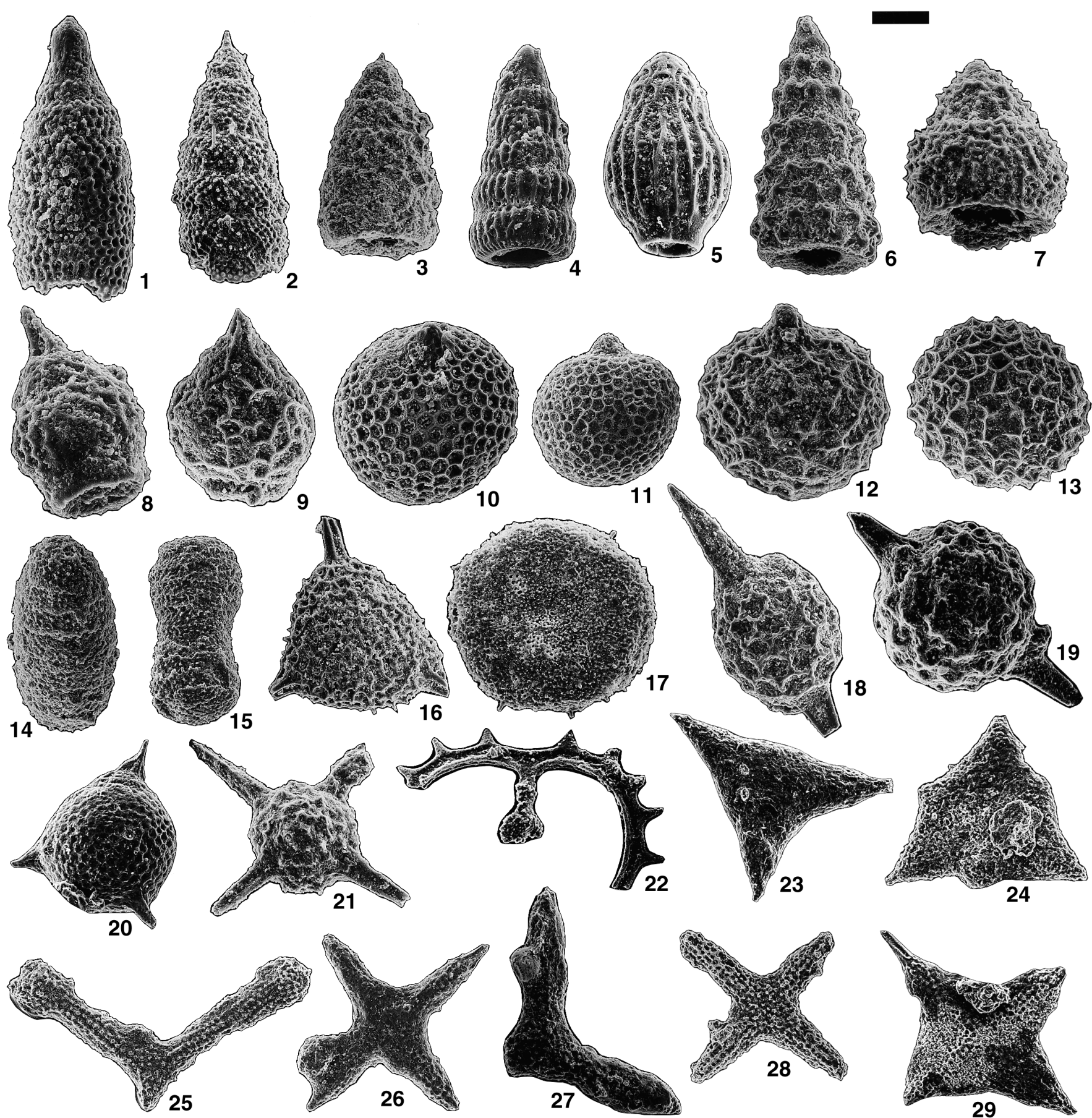

Plate 2. Scale bar $=40 \mu \mathrm{m}$ for Figures 1, 4, 5, 7, 8, 9, and 12; $50 \mu \mathrm{m}$ for Figures 2, 10, 11, 13, 18, 19, 20, and 21; $65 \mu \mathrm{m}$ for Figures 3, 16, 17, and 27; $100 \mu \mathrm{m}$ for Figures 6, 14, 15, 22, 23, 24, 26, 28, and 29; and $200 \mu \mathrm{m}$ for Figure 25. 1. Stichomitra stocki Sample 159-962B-9H-CC, 11-13 cm. 2. ?Xitus sp. cf. X. spicularius Sample 159-962B-9H-2, 88-92 cm. 3. Xitus spinosus Sample 159-962B-10H-CC, 19-21 cm. 4. Pseudodictyomitra lodogaensis Sample 159-962B-9H-2, $88-92 \mathrm{~cm}$. 5. Theocampe apicata Sample 159-962B-9H-2, 88-92 cm. 6. Novixitus mclaughlini Sample 159-962B-10H-CC, 19-21 cm. 7. gen. et sp. indet 1 Sample 159-962B-9H-2, 88-92 cm. 8. Rhopalosyringium mosquense Sample 159-962B-9H-5, 142-146 cm. 9. cryptocephalic nasselaria gen. et sp. indet Sample 159-962B-9H-2, 88-92 cm. 10. Cryptamphorella conara Sample 159-962B-10H-CC, 19-21 cm. 11. Cryptamphorella conara Sample 159-962B-9H-3, 36$40 \mathrm{~cm}$. 12. Cryptamphorella sp. Sample 159-962B-9H-6, $84-88 \mathrm{~cm}$. 13. Cryptamphorella crepida Sample 159-962B-9H-2, 88-92 cm. 14. Cromyodruppa ? concentrica Sample 159-962B-9H-2, 88-92 cm. 15. Cromyodruppa ? concentrica Sample 159-962B-9H-6, 84-88 cm. 16. Alievum sculptus Sample 159-962B10H-CC, 19-21 cm. 17. Orbiculiforma sp. Sample 159-962B-9H-2, 88-92 cm. 18. Dicroa rara Sample 159-962B-9H-3, 36-40 cm. 19. Acaeniotyle umbilicata Sample 159-962B-8H-4, 85-86 cm. 20. Triactoma sp. Sample 159-962B-8H-4, 85-86 cm. 21. Acaeniotyle amplissima Sample 159-962B-8H-6, 80-84 cm. 22. Acanthocircus aff. multidentatus Sample 159-962B-8H-6, 137-141 cm. 23. Cavaspongia sphaerica Sample 159-962B-8H-4, 85-86 cm. 24. Cavaspongia euganea Sample 159-962B-8H-4, 85-86 cm. 25. Patulibracchium sp. Sample 159-962B-8H-6, 80-84 cm. 26. Crucella messinae Sample 159-962B-8H-5, 65-69 cm. 27. Angulobracchia digita Sample 159-962B-8H-6, 137-141 cm. 28. Savaryella quadra Sample 159-962B-8H-5, 34-36 cm. 29. Crucella irwini Sample 159-962B-8H-CC, 14-16 cm. 